\title{
Teori Sastra Semiotik-Feminisme dalam Novel al-Ajnihah al-Mutakassirah Karya Kahlil Gibran
}

Wulandari

wulandari@syekhnurjati.ac.id

Jurusan Bahasa dan Sastra Arab

IAIN Syekh Nurjati

- Received: 12.03 .2019

- Accepted: 02.04.2019

- Published online: 07.05.2019

\begin{abstract}
A literary work has strong correlation with the factors behind its. Literary work is expressed socio-cultural background of the author, ideas and its concepts, included feminist issue, therefore that novelette al-Ajnihah al-Mutakassirah as a literary work unveiling inequality gender relations between man and woman and these was of Gibran's criticism ton feminist issues in a literary work that considered that patriarchal norms dominated various literary genres, especially Arabic literature. This study used the semiotic Michael Riffaterre analyzing a heuristic and hermeneutic approach and feminist literary criticism. Each approach used to dismantle the signs and symbols and analyze how the feminist idea of the author in the text when faced of the male's domination and how the image of woman explored by the author, image of woman as the victims or image of woman who fight for the gender equality. In a correlation with feminism, there are many researcher had studied with the feminism approach, but according to researcher there was not one researcher study yet when feminism approach combine with semiotic study focused in teory and practise. If There, it was focus instead on Poetry. This study also focused to see a figure of Kahlil Gibran from various perspective, one of them through feminism.
\end{abstract}

Keywords: Feminist Literary Criticism, Gender, Patriarchy, Inequalities, Kahlil Gibran 


\section{Pendahuluan}

Studi sastra selama ini masih dianggap sebagai sebuah disiplin ilmu yang hanya berkutat pada teks-teks sastra, pembahasannya hanya seputar sintaksis dan morfologis. Asumsi semacam ini tidak hanya terjadi dalam masyarakat Indonesia, namun juga di dunia Arab (Kamil, 2012). Bahkan di dunia akademisi juga masih banyak yang mengasumsikan bahwa studi sastra merupakan disiplin ilmu yang monodisipliner, bukan interdisipliner. Kecenderungan dan asumsi seperti ini, pada akhirnya berdampak kepada hasil penelitian-penelitian sastra yang 'kering', 'sempit' dan cenderung bersifat deskriptif belaka. Di beberapa sentral penelitian, hasil penelitian hanya menggunakan teori-teori struktural yang menitikberatkan pada aspek instrinsik bahasa yang berkutat sebatas pada hal-hal teoritik sastra. Penelitian sastra model ini lebih mengarah kepada kepentingan sastra untuk sastra (Art to Art). Memang, pemahaman karya lewat karya sastra sendiri itu tidak salah, namun unsur dan faktor-faktor di luar sastra pun harus dipertimbangkan (Endraswara, 2011).

Padahal, teori-teori sastra semacam Kritik Sastra Feminis, Sosiologi Sastra, Psikologi Sastra, Antropologi Sastra, Teori Sastra Marxis, Resepsi, Metode Eksperimen, Postmodernisme dan Poskolonialisme justru masih sangat jarang digunakan (Manshur, 2012). Kajian teori sastra dengan kajian interdisipliner ini membuka ruang lingkup sastra menjadi lebih luas, sehingga peran peneliti menjadi penting untuk menjembatani antara teori struktural sastra dengan faktor-faktor yang membelakanginya seperti, feminisme, sosiologi, psikologi, dan lain-lain. Penelitian tersebut pada akhirnya menjadi sebuah penelitian yang komprehensif dan berdampak langsung terhadap budaya masyarakat (cultural society).

Sastra secara definitif adalah bagian dari entitas budaya yang wujudnya tercermin dalam karya-karya sastra berupa konstruksi kenyataan yang diciptakan oleh pengarang melalui imajinasinya setelah melalui pergumulan kehidupan nyata yang dialaminya. Sastra merupakan ramuan yang memadukan antara kehidupan 
nyata diluar diri pengarang dan dunia yang ada di dalam diri pengarang. Karya sastra diciptakan oleh seorang pengarang di mana posisi pengarang juga merupakan produk dari sistem nilai (kebudayaan) yang melingkupinya. Hal ini berarti, bahwa terciptanya sebuah karya sastra merupakan hasil dialog yang terus menerus antara pengarang dengan sistem nilai tersebut. Meskipun antara produk sastra dengan kondisi lingkungan di mana karya sastra itu diciptakan memiliki hubungan yang sangat erat. Akan tetapi, karya sastra bukan potret hitam putih dari sebuah kenyataan sosial. Hal ini karena posisi pengarang dalam karyanya tidak mungkin netral, pasti ada kecenderungan yang dibuat oleh pengarang untuk menunjukkan sikap dan realitas sosial yang ada di lingkungannya atau di mana karya sastra itu dibuat.

Menurut Selden, Ketika kita membaca sebuah karya sastra, secara tidak langsung kita telah memasuki dunia sosial atau komunitas manusiawi berdasarkan pemikiran dan perasaan si pengarang. Karya sastra disini merupakan media untuk mengungkapkan ide dan gagasan seorang pengarang termasuk di dalamnya sastra feminis. Sastra feminis melihat sastra dalam keterkaitannya dengan gagasan dan ideologi bahwa kanon sastra kita selama ini masih memiliki ideologi tunggal dan bias gender. Berdasarkan masalah tersebut, kaum feminis menilai dan memandang perlu adanya penyusunan dan penilaian ulang mengenai kondisi kesusastraan yang pada akhirnya kita kenal dengan Kritik Sastra Feminis (Feminist Literacy Criticism). Dalam bukunya "In The Shadow Of Change: Citra Perempuan Dalam Sastra Indonesia", Tineke Hellwig mengatakan bahwa melalui pendekatan kritik sastra feminis, kita akan tahu bagaimana sebuah teks dalam merepresentasikan perempuan, bagaimana teks mendefinisikan tentang feminitas dan maskulinitas, bagaimana teks menegaskan, mempertanyakan dan mengkritik ideologi gender yang ada dalam sebuah karya sastra baik yang ditulis oleh pengarang laki-laki maupun pengarang perempuan dan bagaimana pula citra dan gambaran yang dikemukakan pengarang dalam karya sastranya. 
Citra perempuan dalam sebuah karya sastra dan pencitraan perempuan oleh pengarang, tidak hanya dilihat dari karya-karya pengarang perempuan dan tokoh feminis perempuan, tetapi juga dapat dilihat dari karya-karya pengarang laki-laki. Jubran Khalil Jubran atau lebih dikenal dengan Kahlil Gibran (selanjutnya penulis akan menyebut Gibran) adalah salah satu dari beberapa sastrawan dan penyair laki- laki yang karyanya sudah mendunia. Gibran juga adalah sosok penyair Lebanon yang banyak menginspirasi orangorang Indonesia. Di Indonesia, puisi-puisinya Gibran memang lebih popular dibandingkan noveletnya. Puisi-puisinya banyak dikutip terlebih oleh para Gibranis, sebutan untuk para penggemar Gibran. Gibran juga dikenal sebagai Sang Sufi (The Mystic), Sang Filosof (The Philosopher), Yang Religius (The Religious), Si Kufur (The Heretic), yang Cemerlang (The Serene), Sang Pemberontak (the Rebellious) dan Yang Abadi (The Ageless). Karya-karya Gibran merupakan salah satu karya penting yang sudah memperoleh pengakuan karya monumental baik di peradaban bangsa Arab dan Barat.

Dalam karya-karyanya, Gibran menekankan kecintaan kepada Tuhan, tanah air, keluarga, lingkungan hidup dan kemanusiaan secara universal. Gibran dikenal sebagai "Sang Nabi Abadi dari Lebanon" dan orang terpelajar pada zamannya, Gibran adalah sastrawan yang berjasa besar dalam menyebarkan ide-ide inovatif dan mendorong renaissance dalam kreatifitas orang-orang Arab. Ketika kondisi sastra Arab berada pada masa yang memprihatinkan "kitsch", yaitu seni semu yang oleh Eco, seorang linguis Italia disebut "sebuah dusta struktural", Gibran merupakan satu di antara beberapa sastrawan yang ikut terlibat dalam upaya penegakan kembali sastra Arab al-Inbi'ats (Renaissance) yang untuk pertama kalinya dimulai di Lebanon, Suriah, dan Mesir.

Dari sekian banyak penilaian dan predikat yang terkumpul dalam pribadi Gibran sebagai tokoh pembaharu dan dapat diterima secara luas di dunia Arab. Karya-karyanya memiliki tema keadilan, kebebasan dan ketuhananan dan sejauh yang penulis ketahui, masih sedikit yang mengungkapkan pandangan feminisme Gibran dalam memotret citra perempuan dalam bentuk sebuah 
penelitian ilmiah. Padahal dalam beberapa karya sastra yang ditulis Gibran banyak mengangkat persoalan perempuan dalam masyarakat patriarki di Lebanon. Oleh karena itu, penulis sangat tertarik untuk melakukan penelitian tentang Gibran dan karya sastranya dari sisi yang berbeda. Gambaran dan sikap perempuan dalam karya sastra tersebut akan mampu mencerminkan bagaimana jiwa pengarang masuk dalam karya-karyanya (Implied Author) dan mampu menunjukkan sikap pengarang terhadap isu gender yang ada dalam karya yang ditulisnya cenderung mendukung sistem patriarkhi atau sebaliknya. Di antara karya monumental Gibran yang layak untuk dijadikan studi penelitian untuk melihat hubungan antara sastra, gender dan feminisme adalah novelet al-Ajnihah al-Mutakassirah (Jubran, 1949).

Novelet ini merupakan gambaran otobiografi Gibran yang memiliki pengaruh besar terhadap dunia Arab karena dengan terbitnya novelet ini, para perempuan yang selama ini selalu terkukung dalam norma-norma yang mengikat seolah mendapat kesempatan untuk berbicara dan memprotes struktur kekuasaan yang diatur dalam perkawinan. Selain itu novelet Al-ajnihah alMutakassirah merupakan salah satu karya Gibran yang terbit di New York dan juga merupakan novelet pertama Gibran yang berhasil menduduki daftar best seller dunia lebih lama dari yang dicapai oleh an-Nabi (The Prophet) dan merupakan karya Gibran yang terbaik dalam bahasa Arab. Struktur cerita novelet ini sangat sederhana untuk ukuran sebuah novel, namun memiliki kelebihan dalam hal gaya bahasa. Gaya bahasa yang digunakan adalah gaya bahasa metafora dan simile yang dihiasi dengan gaya ironi dan paradox.

Disinilah penting penulis menggunakan pendekatan semiotik dengan pembacaan heuristik dan hermeneutik guna memahami keseluruhan cerita dalam novelet ini secara utuh dimana aspek feminisme juga sangat kental menjadi topik pembahasan. Dalam hubungannya dengan feminisme misalnya, sudah ada beberapa akademisi yang mengkaji novelet dengan pendekatan kritik sastra feminis, namun ketika pendekatan feminisme disandingkan dengan studi semiotik, sepengetahuan penulis belum ada akademisi yang 
mengkaji sebuah novelet dengan perspektif Semiotik-Feminisme yang memfokuskan pada teori dan praktiknya. Jikalaupun ada obyek kajian yang digunakan adalah sajak (puisi) bukan karya fiksi (novelet). Penelitian ini mencoba untuk melihat sosok seorang Gibran melalui berbagai kacamata di antaranya melalui sastra feminisnya.

Meskipun Kahlil Gibran bukanlah seorang feminis, namun menurut hemat penulis justru menarik apabila karya-karya Gibran diteliti secara mendalam melalui perspektif kritik sastra feminis. Hal ini dikarenakan selain karya-karya Gibran banyak memasukkan tokoh dan penokohan perempuan baik itu sebagai tokoh utama maupun tokoh pendukung.

Berdasarkan permasalahan di atas, maka penulis melalui penelitian sastra dengan pendekatan semiotik-feminisme ini penulis mencoba untuk membongkar ideologi pengarang khususnya pengarang laki-laki di balik penciptaan karya sastra. Seorang pengarang disadari ataupun tidak telah mengkonstruksi nilai-nilai dan gagasannya melalui tokoh-tokoh rekaannya dalam sebuah karya sastra yang diciptakannya. Dalam sastra Arab modern, Kahlil Gibran lebih dikenal dengan kritik politiknya, sehingga menurut sepengetahuan penulis, sejauh ini meskipun karya Gibran sudah banyak diterjemahkan kedalam pelbagai macam bahasa, belum ada satupun peneliti yang melakukan kajian feminisme terhadap karya sastra Gibran dalam hal ini novelet menggunakan pendekatan semiotik-feminisme.

\section{Metode}

Penelitian ini menggunakan objek material berupa Novelet Arab yang berjudul al-Ajnihah al-Mutakassirah (Sayap-Sayap Patah) yang ditulis oleh Gibran Khalil Gibran, seorang sastrawan Arab dengan maha karya sastranya yang tidak lekang di makan zaman. Adapun obyek formalnya adalah perjuangan perempuan yang menuntut perubahan dan kebebasan dari budaya patriarkhi yang mengekang kaum perempuan yang teks tersebut terkandung dalam cerpen. Penelitian ini menggunakan teori semiotik dan kritik sastra 
feminisme, dengan dasar pemikiran perjuangan yang begitu berat untuk menciptakan citra baru perempuan yang bukan khas patriarkhi, selaras dengan tujuan kritik sastra feminisme. Secara teoritis, penelitian ini dilakukan untuk menggali lebih jelas bagaimana gambaran perempuan dalam karya sastra Gibran melalui pendekatan semiotik dan kritik sastra feminis, apakah cenderung mengukuhkan citra perempuan yang khas patriarkhi ataukah citra baru bagi perempuan sebagai sosok yang mandiri, berani dan lantang dalam menyampaikan gagasan dan keinginannya. Adapun secara praktis, penelitian ini juga ingin membuktikan sisi lain dari seorang Gibran yang selama ini digambarkan hanya fokus terhadap soal keluarga, pendidikan, cinta tanah air dan lain-lain.

Penelitian ini menggunakan pendekatan semiotik model Michael Riffaterre, pendekatan model ini menggunakan pembacaan sastra lewat dua analisis, yaitu heuristik dan hermeneutik. Heuristik disini maksudnya adalah pembacaan novel dengan menganalisa teks secara berurutan dari awal hingga akhir cerita yang di dalamnya juga dibahas unsur-unsur intrinsikalitas sastra yaitu tokoh, alur, gaya bahasa dan setting. Tanpa analisis heuristik ini maka keutuhan makna dari sebuah teks sastra tidak mampu ditangkap. Sedangkan temanya dibahas secara hermeneutik. Hermeneutik disini adalah proses penguraian teks novelet yang bertolak dari isi dan makna teks yang tampak lalu menuju makna pesan yang bersifat inner dan tersembunyi. Tujuannya agar dapat mengungkapkan makna sesungguhnya dari sebuah teks dengan menggunakan akal kontemplatif dan imajinasi kreatif berdasarkan tanda-tanda qarinah yang sudah ditemukan dalam analisis heuristik sebelumnya lalu digabungkan dengan analisis eksternal sastra yaitu konteks lahirnya novelet tersebut. Analisis ekternal disini mencoba memotret bagaimana ideologi yang dianut pengarang dan masyarakat ketika karya sastra tersebut diciptakan dalam memandang posisi perempuan, sehingga pendekatan yang lebih tepat digunakan adalah kritik sastra feminisme.

Dengan asumsi bahwa untuk mengungkap gagasan yang ada di dalam karya ini tidak bisa berdiri sendiri, harus ada kesatuan 
antara satu dengan yang lainnya, yaitu analisis intrinsik dan ekstrinsik sastra, maka berdasarkan pertimbangan inilah peneliti akhirnya menggunakan perpaduan teori interdisipliner dengan menggabungkan teori semiotik dan kritik sastra feminisme menjadi teori semiotik-feminisme. Menurut pengamatan peneliti, sudah banyak akademisi yang menggunakan teori semiotik dan teori kritik sastra feminisme dalam menganalisis sebuah karya sastra. Menurut pengamatan peneliti, masih sangat langka peneliti temukan akademisi yang menganalisi karya sastra dengan metode pendekatan semiotik-feminisme. Jikalaupun ada, obyek kajian yang diteliti berupa sajak (puisi) dan bukan prosa (novelet).

Dengan menggunakan metode sastra interdisipliner, kajian sastra lebih mampu menjawab persoalan pragmatis yang dihadapi manusia, kajian sastra tidak hanya dibatasi pada penambahan kosakata dan pengembangan keterampilan bahasa semata. Penerapan sastra interdisipliner ini menurut Arif Rahman memiliki 3 (tiga) keuntungan, yaitu: pertama, perspektif interdisipliner tidak mengasingkan diri dari studi-studi kemanusiaan. Kedua, pendekatan studi interdisipliner yang menjadikan karya sastra sejajar dan setara dengan ilmu sosiologi, antropologi, sejarah dan disiplin ilmu lainnya. Hal ini menjadikan sastra menjadi hal yang tidak lagi kaku dan monoton, sastra mampu menjawab persoalan manusia dengan berbagai macam kompleksitasnya. Dan yang ketiga, dengan kajian sastra interdisipliner, masyarakat akan melihat persoalan dan realitas sebagai kesatuan yang utuh dan komprehensif (Rokhman, 2003).

\section{Hasil dan Diskusi}

\section{Teori Sastra Semiotik}

Bahasa yang digunakan pengarang dalam karya sastra disini bukanlah bahasa dalam arti sesungguhnya, namun bahasa khas yang memuat tanda-tanda atau semiotik. Karena tanda adalah menandai bahwa sesuatu itu penting, maka yang dicari dalam sebuah penelitian adalah tanda yang penting, tanda yang bermakna. Culler mengemukakan bahwa meneliti sastra itu dapat diartikan dengan memburu tanda-tanda (The Pursuit of Signs). Tanda-tanda yang 
bermakna tersebut dapat berupa: ikon, simbol maupun indeks.(Pradopo, 2008). Bahasa yang membentuk sistem ketandaan tersebut kita kenal dengan semiotik. Sedangkan Ilmu yang mempelajari masalah ini adalah semiologi. Bahasa lain dari semiologi adalah semiotika yang merupakan ilmu yang mempelajari tandatanda dalam karya sastra.

Dari uraian diatas, dapat kita pahami bahwa kajian semiotik merupakan kajian mengenai tanda. Tanda-tanda yang ada dalam sebuah karya sastra harus dapat dipahami secara baik oleh peneliti, agar dapat memahami sebuah karya sastra secara maksimal sesuai dengan tujuan dan maksud pengarang.

Analisis semiotik ini sebenarnya hampir serupa dengan analisis strukturalisme atau instrinsik, yang menitikberatkan pada teks sastra. Pendekatan intrinsik dan ekstrinsik ini pertama kali diperkenalkan oleh Wellek dan Warren (1989) untuk membedakan antara pengkajian konteks karya sastra yang bersumber pada teks itu sendiri secara otonom (intrinsik) dan pengkajian konteks karya sastra di luar teks (Endraswara, 2011)

Tanaka (1976:9) juga memperkenalkan pendekatan yang pengertiannya senada dengan yang disampaikan oleh Wellek dan Warren, namun hanya berbeda penyebutan yaitu Mikro Sastra dan Makro Sastra. Abrams (1976: 8-26) mengemukakan pendekatan yang lebih spesifik lagi menjadi 4 bagian, yaitu pendekatan ekspresif berhubungan dengan pengarang, pendekatan obyektif berhubungan dengan teks sastra, pendekatan mimetik berhubungan dengan kesemestaan (universe) dan terakhir pendekatan pragmatik yang berhubungan dengan resepsi pembaca terhadap teks sastra.

Jika kita bandingkan dengan dua pendekatan yang dikemukakan oleh Abrams juga memiliki kesamaan dengan yang diungkapkan oleh Wellek dan Warren dan Juga Tanaka. Pendekatan obyektif bisa dimasukkan ke dalam kategori pendekatan intrinsik atau menurut istilah Tanaka adalah termasuk Mikro Sastra. Lalu pendekatan mimetik, ekspresif dan pragmatik masuk dalam kategori penelitian ekstrinsik atau Makro Sastra. 
Lahirnya teori semiotik ini merupakan ketidakpuasan terhadap kajian struktural. Jika kajian struktural hanya menitikberatkan kepada aspek intrinsiknya. Maka kajian semiotik meyakini bahwa karya sastra itu memiliki sistem tersendiri, oleh karena itu lahirlah kajian struktural semiotik yang mencoba mengkaitkan antara aspek intrinsik dengan tanda-tanda, karena sekecil apapun tanda tersebut tetap harus diperhatikan.

Substansi tanda dalam kajian semiotik ini dibagi beberapa macam sesuai dengan kajiannya masing-masing. Barthes (Kurniawan, 2001:56) membagi tanda menjadi 4 substansi, yaitu substansi ekspresi, bentuk ekspresi dari aturan-aturan sintagmatik dan artikulator, substansi isi, dan bentuk isi. Peirce menawarkan 3 sistem tanda yang harus diungkap, yaitu tanda itu sendiri, hal yang ditandai, dan sebuah tanda baru yang terjadi dalam batin penerima tanda. Antara tanda dan yang ditandai ada kaitan representasi (menghadirkan). Lotman tak sekadar mempelajari hubungan intratekstual dalam sastra, namun juga berhubungan dengan ekstratekstual. Fokkema dan Kunne-Ibsch (1977:166) menekankan semiotik sekurang-kurangnya perlu memperhatikan tiga aspek utama, yaitu (a) The Construction Of Abstract Scientific Models, (b) Explanatory Models, and (c) Schematic Simplication. Sedangkan jenis penelitian semiotik yang digunakan dalam penelitian yaitu semiotik menurut Riffaterre (1978: 1-2), yaitu perlu memperhatikan tiga aspek penting, seperti: (a) Displacing of Meaning (Penggantian Arti), (b) Distorting of Meaning (Penyimpangan Arti), (c) Creating of Meaning (Penciptaan Arti). Meskipun analitik jenis ini banyak digunakan dalam puisi, namun juga bisa digunakan pada genre lain, seperti puisi dan prosa (Endraswara, 2011). Sebagaimana penulis menggunakan analitik menurut Riffaterre ini dalam kajian novelet al-Ajnihah al-Mutakassirah (Sayap-Sayap Patah) karya Kahlil Gibran.

Displacing of Meaning (Penggantian Arti) dalam karya sastra, biasanya disebabkan oleh bahasa qiyas, seperti: metafora, personifikasi, alegori, metonimi dan lain-lain. Dalam bahasa Arab, Metafora sering kita sebut dengan istilah Tasbih merupakan majaz yang mengandung perbandingan yang tersirat menyamakan sesuatu 
hal dengan hal yang lain. Tasbih dibagi menjadi dua, yaitu Tasbih Mursal Mujmal (Simile) majaz perbandingan yang menggunakan kata pembanding dan Tasbih Baligh yang tidak menggunakan kata perumpamaan seperti atau bagaikan dan juga tidak menyebutkan Musyabbah (kata yang diserupakan) dan Musyabbah Bih (kata yang dianggap menyerupai). Misalnya penggunaan Tasbih Mursal Mujmal yang digunakan Gibran dalam noveletnya:

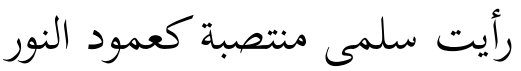

Aku melihat Salma berdiri tegak di hadapanku seperti pilar cahaya

(Sayap-sayap patah: Pengantar, 169)

Metafora disini mencoba mengkiaskan perempuan bernama Salma Karamy yang merupakan tokoh utama dalam novelet sayapsayap patah seperti pilar cahaya. Hal ini, berarti penyair ingin meyampaikan bahwa kehadiran perempuan tersebut memberikan kedamaian dan ketenangan, yang tadinya hati gelap dan sepi menjadi lebih indah dan berwarna. Sedangkan Distorting of Meaning (peyimpangan arti), bisa muncul karena 3 hal, yaitu Ambiguitas, Kontradiksi, dan Nonsense. Ambiguitas muncul karena pemakaian bahasa yang multi makna, misalkan saja kata "penderitaan yang menusuk hati seperti benih yang semakin lama semakin banyak tumbuh di hatiku" (Sayap-sayap patah: Duka Cita Yang Hening, 173), jelas melukiskan ambigu makna yang berarti penyakit, masalah, kesulitan, musibah dan cobaan. lalu kontradiksi yang biasanya berupa perlawanan situasi, misalkan kata hidup dan mati dalam kalimat:

"Sesungguhnya kebodohan itu menggiring kepada kehampaan dan kehampaan membuat manusia riang, hal itu bisa jadi benar bagi orang-orang yang hidup namun seperti orang mati dan mereka hidup bagaikan jasadjasad yang beku diatas pasir" (Sayap-sayap patah: Dukacita Yang Hening, 173)

Nonsence, yaitu kata-kata yang secara lingual tidak bermakna. Hal ini muncul karena permainan bunyi, misalkan pada puisi Amuk karya Sutardji Calzoum Bachri ada kata-kata pot pot, lalu puisi Sepi 
Watu karya Turiyo Ragilputro ada kata sepi watu, watu-watu, watuwatu sepiku sepi watu. dan seterusnya. Sedangkan Creating of Meaning (penciptaan arti), biasanya tampak sekali dalam permainan tipografi dalam puisi, misalnya pada puisi Tragedi Winka dan Sihka karya Sutardji Calzoum Bachri yang berbentuk Z, tentu ada makna sendiri. Sedangkan dalam prosa, penciptaan arti pun tentunya ada dan tergantung kemampuan penyair mempengaruhi pembaca. Penciptaan arti ini biasanya secara lingual tidak memiliki makna yang jelas, namun ketika ditafsirkan secara keseluruhan ternyata memiliki makna yang dalam.(Endraswara, 2011)

Sistem kerja penelitian semiotik ini menggunakan dua model pembacaan, heuristik dan hermeneutik. Pembacaan heuristik adalah pembacaan sastra berdasarkan struktur kebahasaan, yaitu dengan menelaah secara teliti dan seksama kata-kata, bait-bait (line) dan term-term karya sastra. Yang dilakukan dalam heuristik disini adalah menerjemahkan, memperjelas makna-makna yang samar dan tersembunyi dan menjelaskan sinonim-sinonim yang terkandung di dalam teks sastra (novelet). Pemaknaan dilakukan secara semantis, lalu dihubungkan dengan antar baris dan bait atau dalam prosa mengaitkan antara satu makna kata dengan makna kata yang lainnya - Secara semiotik pembacaan semacam ini baru semiotik tingkat pertama. Sedangkan pembacaaan hermeneutik merupakan penafsiran atas totalitas karya sastra. Pembacaan karya sastra ini merupakan pembacaan karya sastra berdasarkan sistem semiotik tingkat kedua atau berdasarkan pada konvensi sastra.

\section{Teori Analisis Feminisme}

Budaya patriarki merupakan perwujudan dari ideologi hegemoni yang mengasumsikan bahwa laki-laki merupakan the authority dan perempuan sebagai the second sex, warga kelas dua dan tersubordinasi (Fachrani, 2015). Begitupun yang terjadi di hampir seluruh karya sastra, baik itu penulis pria maupun wanita. Figur lakilaki digambarkan lebih kuat dan punya otoritas lebih dibandingkan perempuan. Dominasi laki-laki terhadap perempuan ini pada akhirnya turut mempengaruhi kondisi sastra, antara lain: 1) Nilai dan 
konvensi sastra masih terus didominasi oleh kekuasaan laki-laki, sedangkan perempuan masih dalam tahap berjuang yang terus menerus, (2) Penulis laki-laki cenderung memberikan penilaian yang tidak obyektif dan berat sebelah, wanita selalu digambarkan sebagai sosok yang lemah, lembut dan obyek kesenangan bagi laki-laki, (3) Wanita dalam sastra selalu dianggap sebagai bunga-bunga sastra.

Atas dasar itu, peneliti sastra ditantang untuk dapat menggali lebih jauh konstruksi gender dalam sastra dari waktu ke waktu. Peneliti perlu menjelaskan bagaimana peran dan tokoh perempuan dalam sastra, bagaimana keterjajahan perempuan dalam aspek pendidikan dan sosial kemasyarakatan, lalu peneliti juga harus mampu melihat bagaimana tanggapan dan respon pembaca terhadap konsep emansipasi wanita dalam sastra. Konsep-konsep tradisional yang masih menganggap bahwa perempuan hanya lebih tepat di ranah domestik dan tidak memiliki otoritas dan peran di ranah publik menjadi bahan penelitian yang perlu dikaji (Endraswara, 2011).

Hal tersebut selaras dengan tujuan kritik sastra feminis sebagaimana yang dikemukakan oleh Kuiper (Sugihastuti dan Suharto, 2002:68), yaitu: 1) Mengkritik kanon karya sastra dan beberapa hal terkait budaya patriarkhi yang sudah melekat di masyarakat, 2) Menampilkan teks-teks yang diremehkan yang dibuat oleh perempuan, 3) Mengokohkan Gynocritic, sebuah pendekatan yang digunakan untuk mengkaji karya sastra yang ditulis oleh perempuan, 4) Mengeksplorasi konstruksi kultural dari gender dan identitas.

\section{Novelet al-Ajnihah al-Mutakassirah Ditinjau dari Teori Semiotik- Feminisme}

Pendekatan struktural semiotik mengungkap karya sastra sebagai sistem tanda. Tanda yang dimaksud dalam novel al-Ajnihah al-Mutakassirah disini dikhususkan untuk diksi dan kiasan bahasa. Melalui pendekatan semiotik, tanda-tanda dan simbol akan menjadi interpretasi baru yang tidak hanya bermanfaat buat peneliti, namun juga masyarakat dan sejarah dunia. Kata-kata Gibran di dalam novelnya banyak menggunakan tanda-tanda dan simbol yang cukup 
mengasa daya pikir pembacanya secara kritis. Dan setelah membaca lebih lanjut banyak isi dan tokoh di dalam novelet tersebut yang mengandung isu-isu feminisme.

Berdasarkan uraian mengenai teori sastra semiotik dan feminisme, dapat disimpulkan bahwa novelet al-Ajnihah alMutakassirah karya Kahlil Gibran cocok dan sesuai diterapkan teori semiotik feminisme, mengingat setelah penulis cermati karya Gibran di novel ini banyak mengangkat tema perempuan. Sugihastuti menjelaskan bahwa pikiran dan tindakan para tokoh cerita mengenai eksistensi dan representasi perempuan bisa dianalisis melalui pembicaraan maupun lakuan antar tokoh cerita secara khusus yang dikemukakan oleh para tokoh profeminis di dalam novelet.

Melalui pendekatan semiotik dengan analisis heuristiknya, karya Gibran al-Ajnihah al-Mutakassirah tidak bisa dikategorikan sebagai novel ataupun cerita pendek, tapi lebih tepatnya masuk dalam kategori novelet atau dalam bahasa Arab dikenal dengan Uqsusiyah, yaitu cerita yang berbentuk prosa yang panjangnya antara novel dan cerita pendek. Hal ini dilihat dari segi ketebalan novel sekitar 200 halaman dan cerpen 5-15 halaman, maka Novelet sekitar 60-100 halaman. Sebagian ahli seperti Abd al-Azizi bin Muhammad al-Faisal menyebut novelet itu adalah cerita pendek yang panjang (AlFaisal, 1985).

Dalam bahasa Arabnya novelet al-Ajnihah al-Mutakassirah ini merujuk kepada buku berjudul al-Majmuah al-Kamilah Lil Muallafati Jubran Khalil Jubran. Sedangkan dalam bahasa Indonesianya, penulis merujuk kepada terjemahan Anton Kurnia yang berjudul "Karya Terpilih Gibran" (Budianta, 2010). Keduanya menjadi referensi dan rujukan peneliti, meskipun tetap yang edisi bahasa Arab menjadi rujukan utamanya. Menurut analisa peneliti, dalam terjemahan Anton Kurnia ada beberapa teks yang tidak diterjemahkan secara sempurna dan ada juga yang diterjemahkan namun tidak sesuai dengan teks yang dimaksud. Meskipun hal ini tidak merusak plot novelet, namun kekeliruan dalam memilih padanan kata dalam bahasa terjemahan, tentunya akan mengaburkan makna yang dikehendaki teks itu sendiri dan pada akhirnya akan berpengaruhi kepada pembaca dalam 
memahami teks sastra. Misalnya pada bagian awal seri "Dukacita Yang Hening", kata "Antum Ayyuhan Naas" diartikan "Tetanggaku". Menurut penulis makna ini tidak tepat digunakan karena selain mengaburkan makna, makna kata "Tetangga" juga tidak sesuai dari teks aslinya. Menurut peneliti, bahwa kata "Wahai Pembaca" lebih tepat digunakan sebagai terjemahan dari "Antum Ayyuhan Naas". Selain itu juga ada beberapa kata yang tidak diterjemahkan seperti:

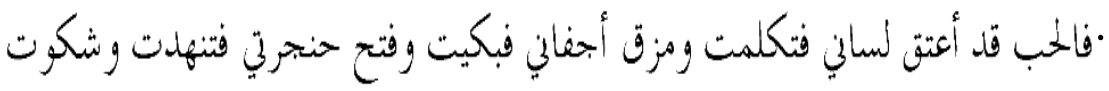

Diterjemahkan "Cinta memberiku Lidah dan Air Mata" Terjemahan tersebut menurut penulis tidak tepat karena pertama pembaca akan bingung dengan makna terjemahan tersebut dan kedua akan muncul multitafsir yang justru dikhawatirkan akan lari dari makna

Setelah mengkaji melalui analisis heuristik. Maka langkah selanjutnya adalah analisis hermeneutik menggunakan pendekatan Kritik Sastra Feminis sebagai alat untuk menganalisis wujud gambaran perempuan dalam novelet al-Ajnihah al-Mutakssirah untuk memaknai teks-teks yang tersembunyi maknanya. Selain mengidentifikasi tokoh-tokoh profeminis, kritik sastra feminis juga harus mempertimbangkan percakapan dan lakuan tokoh-tokoh yang anti feminis seperti di dalam novelet al-Ajnihah al-Mutakssirah kita temukan percakapan antara Uskup dengan keponakannya Mansoer Bey yang menganggap bahwa pernikahan tidak lebih dari transaksi untung dan rugi. Pihak laki-laki yang menjadi pihak yang diuntungkan, sedangkan keluarga perempuan menjadi korban yang dirugikan akibat dari sebuah pernikahan.

$$
\begin{aligned}
& \text { إنما الزوجة في أيامنا هذه تجارة مضحكة مبكية يتولى أمورها الفتيان وآباء الصبايا, } \\
& \text { الفتيان يربحون في أكثر المواطن والآباء يخسرون دائما (أمام عرش الموت) }
\end{aligned}
$$

"Pernikahan pada zaman sekarang seperti sebuah transaksi yang menggelikan sekaligus menyedihkan, pernikahan menjadi hak preogratif lakilaki dan orang tua (pihak perempuan). Namun kebanyakan di beberapa negara, para laki-laki justru berada di pihak yang diuntungkan, sedangkan 
orang tua (perempuan) menjadi pihak yang dirugikan. (Di depan singgasana Kematian)."

Makna perkawinan menurut Gibran sebagaimana yang dijelaskan Mohammad Zuhdi justru berbeda dengan apa yang yang dijelaskan diatas, menurutnya Gibran mendefinisikan makna perkawinan sebagai suatu ikatan antara laki-laki dan perempuan yang diciptakan Allah berpasang-pasangan dan berjodoh hingga maut menjemput, namun biarkan ada ruang diantara pasangan tersebut sebagai tempat angin surgawi melintas dan memainkan tarian. Dimana "ruang" yang dimaksud disini menurut Zuhdi dimaknai sebagai privasi yang harus dijaga dan tidak boleh dilanggar diantara kedua pasangan (Zuhdi, 2019). Dari penjelasan tersebut, penulis menilai Gibran cukup seimbang menggambarkan kehidupan antara laki-laki dan perempuan yang memiliki hak dan kewajiban yang sama, tanpa harus melanggar privasi masing-masing. Makna toleransi dan saling menghormati dalam suatu hubungan sangat jelas disini.

Potret perempuan yang tertindas yang tidak mampu menentukan pilihan hidupnya juga tampak pada sosok Salma Karamy yang tidak kuasa menolak permintaan ayahnya ketika ingin dinikahkan dengan ponakan uskup yang bernama Mansour Galib. Ketika permintaan itu datang kepadanya, Salma Karamy merasa bahwa kematian sudah di depan matanya, dia mengartikan makna pernikahan seperti kematian yaitu kegelapan dan kesakitan.

سمعت سلمى هذه الكلمات فتغيرت ملاعها وممدت عيناها كأفا رأت شبح الموت منتصبا أمامها ثم شهقت وتملمت متوجعة كعصفور رماه الصياد فهبط على الحضيض مربتفا بآلامه

"Setelah mendengar kata-kata ini, wajah salma langsung digelayuti mendung dan matanya membeku seolah-olah ia merasakan datangnya kematian lalu ia menjerit seperti seekor burung yang ditembak oleh pemburu, jatuh menderita lalu gemetar karena sakitnya".

Dilihat dari struktur kata dan gaya bahasa, Karya Gibran menggunakan metaphora, atau dalam bahasa Arab dikenal dengan Tasbih. Tasbih merupakan majaz yang mengandung perbandingan 
yang tersirat menyamakan sesuatu dengan hal yang lain (Zaidan, Rustafa, \& Haniah, 1991). Tasbih dibagi menjadi dua yaitu mursal mujmal yang lebih dikenal simile yaitu majaz perbandingan yang menggunakan kata pembanding dan yang kedua Tasbih Baligh yaitu Tasbih yang tidak menggunakan perumpamaan seperti kata: seperti, andaikan, bagaikan dan lain-lain. Selain itu juga Tasbih baligh tidak menyebutkan al-Musyabbah (kata yang diserupakan) dan Musyabbah bih (kata yang dianggap menyerupai). Melihat penjelasan diatas, bisa kita simpulkan bahwa kata-kata yang digunakan narator adalah Tasbih Mursal Mujmal. Sedangkan melalui analisis feminismenya, Narator mencoba menggambarkan konflik batin yang dirasakan Salma Karamy ketika harus menerima perjodohan dengan laki-laki yang sama sekali tidak dia cintai. Kalimat Salma menurut pengamatan penulis tidak sama sekali menyiratkan adanya semacam perjuangan konkrit yang akan dilakukan oleh tokoh Salma, namun hanya berupa pemberontakan pemikiran dan dialog batin yang terkekang yang hal itu sarat sekali dengan potret perempuan yang biasa digambarkan oleh para pengarang laki-laki di beberapa novel Arab.

Hal ini senada dengan apa yang disimpulkan Free Hearty dalam penelitiannya terhadap tiga teks sastra berbudaya Arab Muslim dengan perspektif Feminis Muslim juga menggambarkan adanya kesenjangan-kesenjangan antara budaya patriarkhi dengan eksistensi perempuan yang menimbulkan peristiwa-peristiwa tragis sebagaimana yang dialami oleh Salma Karamy (Hearty, 2005)

\section{Simpulan}

Berdasarkan uraian tentang teori sastra semiotik feminisme dalam novelet Al-Ajnihah Al-Mutakassirah karya Kahlil Gibran dapat disimpulkan sebagai berikut:

Pertama, Karya sastra memiliki ikatan yang kuat dengan faktor-faktor yang melatarbelakanginya. Karya sastra selalu mengungkapkan latar sosial budaya yang melingkari diri pengarang, ideologi dan gagasannya, termasuk di dalamnya isu-isu feminisme. Karya sastra 
merupakan produk ideologi, dan setiap ahli teori sastra memiliki kecenderuan ideologinya masing-masing.

Kedua, Gabungan teori semiotik dan kritik sastra feminisme menjadi teori semiotik-feminisme sangat membantu dan aplikatif dalam menganalisa sebuah novel. Penggabungan kedua teori ini, menjadikan studi sastra sebagai kajian interdispliner yang mampu menjawab persoalan kehidupan manusia dengan segala kompleksitasnya. Melalui teori semiotik-feminisme ini kita bisa melihat bagaimana ideologi pengarang dan bagaimana pandangannya terhadap perempuan.

Ketiga, Kahlil Gibran dalam noveletnya terlihat ikut mengangkat perjuangan perempuan yang menuntut perubahan, namun cara Gibran terkesan sangat berhati-hati, untuk tidak mengatakan 'pasif' dalam mengusung perubahan dan modernisasi tersebut. Artinya Gibran melalui tokoh Salma Karamy sudah ikut menciptakan citra baru perempuan yang kuat, tegas dan mandiri sebagaimana tujuan dari kritik sastra feminisme.

\section{Daftar Pustaka}

Al-Faisal, A. A. bin M. (1985). al-Adab al-Araby wa Tarikhuhu, al-'Asr alJahili wa 'Asr Sadr al-Islam wa al-'Asr al-Umawi. Riyad: Kerajaan Saudi Arabia.

Budianta, E. (2010). Kahlil Gibran di Indonesia. Jakarta: Ruas.

Endraswara, S. (2011). Metodologi Penelitian Sastra: Epistemologi, Model, Teori dan Aplikasi.

Fachrani, J. I. A. A. (2015). Manifestasi Wanita Dalam Budaya

Patriarkhi: Ideologi Dalam Serat Candraning Wanita dan Refleksi

pada Iklan Era Modern. Jurnal Linguistik Terapan.

Hearty, F. (2005). Kontestasi Pemikiran Feminisme dan Ideologi patriarki:

Analisis Pada Tiga Teks Sastra Berbudaya Arab Muslim, Dengan

Perspektif Feminis Muslim. Universitas Indonesia.

Jubran, K. J. (1949). Al-Ajnihah Al-Mutakassirah. In M. Naimy (Ed.), Al-Majmu'ah Al-Kamilah lil Muallafaati Jubran Khalil Jubran. Lebanon: Biskinta.

Kamil, S. (2012). Najib Mahfuz, Sastra, Islam dan Politik: Studi Semiotik 
Wulandari

terhadap novelet Aulad Haratina. Jakarta: Rajawali Press.

Manshur, F. M. (2012). Teori Sastra Marxis Dan Aplikasinya Pada Penelitian Karya Sastra Arab Modern. Bahasa Dan Seni, 40 No. 1.

Pradopo, R. J. (2008). Semiotika: Teori, Metode dan Penerapannya. Humaniora.

Rokhman, M. A. (2003). Sastra Interdisipliner: Menyandingkan Sastra dan Disiplin Ilmu Sosial. Yogyakarta: Qalam.

Zaidan, A. R., Rustafa, A. K., \& Haniah. (1991). Kamus Istilah Sastra. Jakarta: Pusat Pembinaan dan Pengembangan Bahasa Departemen Pendidikan dan Kebudayaan.

Zuhdi, M. (2019). Spiritualitas Sang Nabi (Analisis nilai dekonstruksi dalam puisi prosa Sang Nabi karya Kahlil Gibran). Spiritualita. https:// doi.org/10.30762/.v2i2.1020 